\title{
Long-term decrease of organic and inorganic nitrogen concentrations due to pine forest wildfire
}

\author{
Jorge DURÁN ${ }^{1 *}$, Alexandra Rodríguez ${ }^{1}$, José María FERnÁNDEZ-PALACIOs ${ }^{2}$, Antonio GALLARDO ${ }^{1}$ \\ ${ }^{1}$ Departamento de Sistemas Físicos, Químicos y Naturales, Universidad Pablo de Olavide, Ctra. de Utrera km. 1, 41013 Sevilla, Spain \\ ${ }^{2}$ Departamento de Ecología, Universidad de La Laguna, 38206 La Laguna, Tenerife, Spain
}

Keywords: dissolved organic nitrogen /

labile nitrogen /

microbial biomass /

mineral nitrogen /

Pinus canariensis /

fire

Mots-clés :

azote organique dissous /

azote labile /

biomasse microbienne /

azote minéral /

Pinus canariensis /

incendie

(Received 4 April 2009; accepted 11 August 2009)

\begin{abstract}
- Growing concerns about fires and the increase of fire frequency and severity due to climate change have stimulated a large number of scientific papers about fire ecology. Most researchers have focused on the short-term effects of fire, and the knowledge about the long-term consequences of fires on ecosystem nutrient dynamics is still scarce.

- Our aim was to improve the existing knowledge about the long-term effects of wildfires on forestlabile $\mathrm{N}$ concentrations. We hypothesized that fires may cause an initial decline in organic and inorganic $\mathrm{N}$ availability, and in the amount of microbial biomass-N; this should be followed by the recovery of pre-fire $\mathrm{N}$ concentrations on a long-term basis. We selected a fire chronosequence in Pinus canariensis forests on La Palma Island (Canary Islands, Spain). These forests are under low anthropogenic atmospheric deposition, and forest management is completely lacking; wildfires are therefore the only significant disturbance. Soil samples were collected during the winter and spring at 22 burned and unburned plots.

- Fire produced a significant decrease in microbial biomass $\mathrm{N}$, mineral $\mathrm{N}$ and dissolved organic $\mathrm{N}$. Almost $20 \mathrm{y}$ after fire, pre-fire levels of $\mathrm{N}$ concentrations had not recovered.

- These results demonstrate that $P$. canariensis forest soils have a lower resilience against fire than expected. The magnitude of these observed changes suggests that pine forest wildfires may induce long-term ( 2 decades) changes in soil and in plant primary production.
\end{abstract}

Résumé - Décroissance à long terme des concentrations d'azote organique et inorganique, attribuable au feu dans une forêt de pins.

- Les préoccupations grandissantes au sujet des incendies, de l'augmentation de leur fréquence et de leur gravité attribuable aux changements climatiques ont stimulé la production d'un grand nombre d'articles scientifiques sur l'écologie des incendies. La plupart des chercheurs ont mis l'accent sur les effets à court terme de l'incendie, et les connaissances sur les conséquences à long terme des incendies sur la dynamique des éléments nutritifs de l'écosystème sont encore rares.

- Notre objectif est d'améliorer les connaissances actuelles sur les effets à long terme des incendies sur les concentrations labiles d'azote en forêt. Nous avons émis l'hypothèse que les incendies peuvent provoquer une baisse initiale de l'azote organique et de la disponibilité de l'azote inorganique, et de la quantité de biomasse microbienne azotée, ce qui devrait être suivie par la récupération des concentrations d'azote d'avant le feu sur une base de long terme. Nous avons sélectionné une chronoséquence d'incendies dans des forêts de Pinus canariensis sur l'île de La Palma (îles Canaries, Espagne). Ces forêts sont situées sous de faibles dépôts atmosphériques d'origine anthropique, et la gestion des forêts est totalement absente; les feux de forêt sont donc les seules perturbations importantes. Des échantillons de sol ont été recueillis au cours de l'hiver et du printemps dans 22 parcelles brûlées et non brûlées.

- L'incendie a produit une diminution significative de la biomasse microbienne azotée, de l'azote minéral et de l'azote organique dissous. Presque 20 ans après l'incendie, les niveaux de concentrations d'azote d'avant le feu n'ont pas été récupérés.

- Ces résultats montrent que les sols forestiers de $P$. canariensis ont une résilience contre le feu plus faible que prévu. L'ampleur des changements observés suggère que les feux dans les forêts de pin peuvent induire des changements à long terme ( 2 décades) dans les sols et dans la production primaire des plants.

\footnotetext{
* Corresponding author: humia20@gmail.com
} 


\section{INTRODUCTION}

Many references to nutrient cycling disturbance and forest soil degradation caused by fire may be found in the literature (González et al., 2006; Wan et al., 2001). In the short term, fire may increase ecosystem $\mathrm{N}$ availability, but the long-term effect may lead to losses of total $\mathrm{N}$, causing a significant decline in the availability of this essential soil nutrient (Carreira et al., 1994; Pappa et al., 2008; Rodríguez et al. 2009). Fire may also decrease microbial biomass size, reduce microbial biodiversity and diminish its catalytic capabilities, and these changes may be strong and long-lasting effects (Dumonet et al., 1996; Hernández et al., 1997). Microbial biomass is often regarded as a rapid indicator of long-term changes that may happen to affect soil fertility and other properties (Mabuhay et al., 2003). Thus, knowing how microorganisms are affected by fire may improve the current understanding of how the entire ecosystem is affected. Traditionally, it was believed that plants take only inorganic $\mathrm{N}$ and compete for it with microorganisms, with plants being far more efficient (Vitousek et al., 1979). For this reason, few studies have considered the effects of fire on labile organic $\mathrm{N}$ forms as a key to understanding the overall impact of fires on forest systems. However, organic $\mathrm{N}$ uptake by plants is currently gaining in importance, especially in $\mathrm{N}$-poor systems where plants and microorganisms could compete for mainly organic $\mathrm{N}$ forms (Kranabetter et al., 2007).

The growing concern about fires and their increasing frequency and severity due to climate change have stimulated a large number of scientific papers about fire ecology (Dumonet et al., 1996; Rambal and Hoff, 1998). However, although a shift from short-term to long-term approaches has already occurred in fire-ecology studies since early 1990s, the long-term consequences of fires on nutrient dynamics in ecosystems is still scarce (Mabuhay et al., 2006; Palese et al., 2004). Thus, the main objective of our study was to expand on the existing knowledge about the long-term ( 2 decades) effects of wildfires on forest microbial biomass and the availability of labile organic and inorganic $\mathrm{N}$ forms. For this purpose we used a wildfire chronosequence of unmanaged Pinus canariensis forests located on La Palma Island (Canary Islands, Spain), an area under low atmospheric $\mathrm{N}$ deposition rates (Galloway et al., 2008). Due to the high soil erosion and leaching rates expected during the first years after fire, we hypothesize a decline in organic and inorganic $\mathrm{N}$ availability for plants with a parallel decrease in the amount of microbial biomass-N 4 years after wildfire, but that this should be followed by the recovery of these pre-fire $\mathrm{N}$ concentrations on a long-term basis (17 y).

\section{MATERIALS AND METHODS}

\subsection{Study site}

The study was carried out in forest stands located on La Palma Island (Canary Islands, latitude: $28^{\circ} 41^{\prime} \mathrm{N}$, longitude: $17^{\circ} 45^{\prime} \mathrm{W}$ ). La Palma Island provides an exceptional opportunity to test the proposed working hypotheses, because in these forests it is relatively easy to find plots with similar soil and site characteristics but burned in different years. Three characteristics made these forests unique. First they are one of the last natural and unmanaged pine European forests. Secondly, far from the European continent and with low local $\mathrm{N}$ emissions, the atmospheric $\mathrm{N}$ deposition is very low, being nutrient deficiencies in trees frequently observed, which increase the interest of nutrient cycling studies, due to the recycling of this limiting nutrient should be of primary importance (Galloway et al. 2008; Legout et al., 2008). Thirdly, mature P. canariensis trees resist severe forest fires, being burned stands very comparable in terms of tree structure and age. These stands lie between 1200 and $1800 \mathrm{~m}$ above sea level, with a mean annual rainfall of $600 \mathrm{~mm}$ and a mean annual temperature of $16{ }^{\circ} \mathrm{C}$. Soils are of volcanic origin and are classified as leptosols, vertisols and andosols [A(C) soil profile] derived from the weathering of basaltic rocks. The organic matter content of the sampled areas ranged from 2 to $4 \%$, with total $\mathrm{N}$ ranging from 0.3 to $0.4 \%$ and $\mathrm{pH}$ from $6.6-6.9$. Vegetation was dominated by the presence of large individuals of Pinus canariensis $\mathrm{Chr}$. Sm. ex DC., with an average canopy cover of $80 \%$. The pine population is comprised of adult trees (20-30 m height) and occasionally very old trees (up to 700 years old). The understory vegetation is very scarce, with few individuals of Adenocarpus viscosus (Wild.) Webb and Berthel, Erica arborea L., Cistus symphytifolius Lam., and occasionally also young pine trees. A. viscosus is the only nitrogen-fixer in the plant community, but its plant cover was always below $1 \%$. Fires affecting these forests completely eliminate the undergrowth and, although fire frequently reaches the canopies (crown fires), it rarely kills the trees; so it is common to find individuals that exceed $100 \mathrm{~cm}$ dbh.

\subsection{Experimental design and chronosequence plot selection}

A wide set of fire chronosequence sites can be found in La Palma island, ranging from unburned sites to recent (2005-y) burned sites. However, only a few sites are comparable in terms of altitude, slope, aspect and soil characteristics. Thus, the fire chronosequence was composed of unburned plots (control) and plots burned in 1987, 1990, 1994, 1998 and 2000. For each year and for the control plot, we selected four $25 \times 25 \mathrm{~m}$ replicate plots, except for the 1987 forest stand, where only two replicates with homogeneous characteristics were found. Although each plot does not correspond to an independent fire event, they were chosen in sufficiently separated areas, therefore considered as spatially independent plots. Criteria for plot selection were as follow: all plots were selected at 1200 -to- $1800 \mathrm{~m}$ altitude in mature Pinus canariensis forests (Tab. I); half of the replicate plots were low-slope plots (4-8\%), and half high-slope plots (20-25\%); and similarly, North and South aspect plots were selected in all sites. Soil characteristics were similar across the chronosequence, with a narrow range of total $\mathrm{N}$, organic matter, $\mathrm{C}$ to $\mathrm{N}$ ratio, and $\mathrm{pH}$ (Tab. I). Due to all plots were placed in the North-East face of the island, climate was similar in terms of precipitation. However some differences in temperature could occur because differences in altitude. Fire intensity and severity was assessed by the amount and height of the charcoal black stains deposited on pine bark. Based on these signals and on the information given by a local environmental agency, all fires were classified as crown fires. Previous fire history was also provided by the local environmental agency, and the selected plots were not burned at least before 1967. Fuel conditions were similar in all the plots, in order to avoid differences in fire intensity and severity caused by this parameter (Fernandes et al., 2004). Finally, the plots were also comparable in terms of stand structure (Tab. I). 
Table I. Altitude, stand structure and soil properties of the plots burned in different years and the unburned plots.

\begin{tabular}{lcccccccc}
\hline & Altitude $(\mathrm{m})$ & $\mathrm{DBH}(\mathrm{m})$ & $\begin{array}{c}\text { Basal area } \\
\left(\mathrm{m}^{2} \mathrm{ha}^{-1}\right)\end{array}$ & $\mathrm{OM}(\%)$ & $\mathrm{N}(\%)$ & $\mathrm{C} / \mathrm{N}$ & $\begin{array}{c}\text { Olsen-P } \\
\left(\mathrm{g} \mathrm{kg}^{-1}\right)\end{array}$ \\
\hline Unburned & 1201 & 27.16 & 30.06 & 3.98 & 0.29 & 7.98 & 39.79 & 6.55 \\
1987 & 1603 & 34.38 & 66.66 & 4.17 & 0.41 & 5.91 & 39.15 \\
1990 & 1217 & 35.44 & 33.16 & 3.97 & 0.26 & 8.88 & 23.70 \\
1994 & 1894 & 46.89 & 35.94 & 4.5 & 0.35 & 7.48 & 30.81 \\
1998 & 1364 & 33.82 & 37.53 & 4.08 & 0.28 & 8.47 & 13.12 \\
2000 & 1218 & 35.86 & 26.85 & 4.03 & 0.41 & 5.71 & 6.85 \\
\hline
\end{tabular}

$\mathrm{DBH}=$ Mean diameter at breast height; $\mathrm{OM}=$ Organic matter; $\mathrm{N}=$ Total; $\mathrm{C} / \mathrm{N}=\mathrm{C}$ to $\mathrm{N}$ ratio.

Table II. Effects of last-fire year and sampling date on microbial biomass N (MB-N), mineral N, dissolved organic N (DON), DON-to-mineral $\mathrm{N}$, and LON-to-Mineral $\mathrm{N}$ ratios (Kruskal-Wallis test).

\begin{tabular}{|c|c|c|c|c|c|c|c|c|c|}
\hline & \multicolumn{6}{|c|}{ Fire } & \multirow{2}{*}{\multicolumn{3}{|c|}{ Sampling date }} \\
\hline & \multicolumn{3}{|c|}{ Spring } & \multicolumn{3}{|c|}{ Winter } & & & \\
\hline MB-N & 5 & 100.99 & $<0.001$ & 5 & 89.56 & $<0.001$ & 1 & 4.27 & $<0.05$ \\
\hline DON & 5 & 35.14 & $<0.001$ & 5 & 73.32 & $<0.001$ & 1 & 157.55 & $<0.001$ \\
\hline DON/Min-N & 5 & 20.02 & $<0.005$ & 5 & 73.13 & $<0.001$ & 1 & 186.99 & $<0.001$ \\
\hline LON/Min-N & 5 & 96.43 & $<0.001$ & 5 & 37.53 & $<0.001$ & 1 & 8,72 & $<0.005$ \\
\hline
\end{tabular}

\subsection{Field sampling}

We conducted two samplings, the first in the spring (April, 2004) during the growing season, and the second in the winter (February, 2005), when growth is usually limited by low temperature. In each plot we randomly selected 15 points for soil sampling. Soil samples were collected by using a $15 \times 5 \mathrm{~cm}$ metallic corer, which allowed to sampling of the first top $10 \mathrm{~cm}$ of the soil profile (including the O-horizon and the mineral layer). Litter layer was removed before sampling. Samples were carried to the laboratory in coolers inside polyethylene bags.

\subsection{Laboratory analysis}

We sieved the collected samples with a $2 \mathrm{~mm}$ mesh to remove discrete pieces of stones and undecomposed litter. To calculate the soil properties on a dry weight basis, gravimetric water content of the soil samples was measured by drying a subsample in a forced-air oven at $80{ }^{\circ} \mathrm{C}$ for $48 \mathrm{~h}$. Carbon and organic matter content was estimated by a wet digestion method (Allen et al., 1986). Total $\mathrm{N}$ was estimated by Kjeldahl digestion with sulphuric acid and copper sulfate as a catalyst (Allen et al., 1986). Phosphorus was extracted with $0.5 \mathrm{~N}$ sodium bicarbonate adjusted to $\mathrm{pH}$ 8.5. Phosphate concentration in the extracts was estimated by the Blue Molybdenum method (Allen et al., 1986). We analyzed the mineral $\mathrm{N}$ (ammonium+nitrate) by extracting $5 \mathrm{~g}$ of fresh soil sample with $50 \mathrm{~mL}$ of $2 \mathrm{M} \mathrm{KCl}$. Nitrate was reduced to ammonium by using the Devarda alloy procedure. Then, the amount of $\mathrm{N}$ present in the extracts was calculated by using the blue indophenol colorimetric method (Sims et al., 1995). Microbial biomass N (MB$\mathrm{N}$ ) was determined using the fumigation-extraction method following Brookes et al. (1982). We fumigated $5 \mathrm{~g}$ of fresh soil samples with chloroform for five days. Fumigated soils were extracted with $50 \mathrm{~mL}$ of $0.5 \mathrm{M} \mathrm{K}_{2} \mathrm{SO}_{4}$, and filtered through $0.45 \mu \mathrm{m}$ Millipore filters. We used subsamples extracted with $50 \mathrm{~mL}$ of $0.5 \mathrm{M} \mathrm{K}_{2} \mathrm{SO}_{4}$ just before fumigation for the control. MB-N was calculated by subtracting the total $\mathrm{N}$ of non-fumigated samples to the total $\mathrm{N}$ of the fumigated samples. Total $\mathrm{N}$ in these extracts was calculated using the persulphate oxidation technique (D'Elia et al., 1977) and the colorimetric blue indophenol method mentioned above. Finally, we estimated the dissolved organic nitrogen (DON) by subtracting to the total $\mathrm{N}$ amount in non-fumigated samples the mineral $\mathrm{N}$ obtained in those samples (Cabrera and Beare, 1993). We defined labile organic nitrogen (LON) as the sum of DON and MB-N.

\subsection{Data Analysis}

We used the non-parametric Kruskal-Wallis test to determine the effect of fire on each of the studied variables, and asymptotic permutation tests to know the differences between the plots that were burned in different years and between the plots that were sampled in different season. We conducted Spearman's rank correlation tests to identify the relationships between MB-N, DON and mineral $\mathrm{N}$. To test for significant trends in observed declines of values as time elapsed after the fire, we adjusted the average values of the variables to a regression line with the last-fire year as an independent variable. The analyses were conducted with the statistical package for Linux 2.4.0 R.

\section{RESULTS}

Last-fire year and sampling date (spring or winter) showed a significant effect on all the organic and inorganic $\mathrm{N}$ concentrations $(P<0.05$, Tab. II). Thus, soil microbial biomass $\mathrm{N}$, mineral $\mathrm{N}$ and DON values in burned plots were always lower than those recorded in unburned plots, both in spring and winter sampling (Figs. 1a and 1b). The DON-to-mineral $\mathrm{N}$ and LON-to-mineral $\mathrm{N}$ ratios were also significantly higher in the 

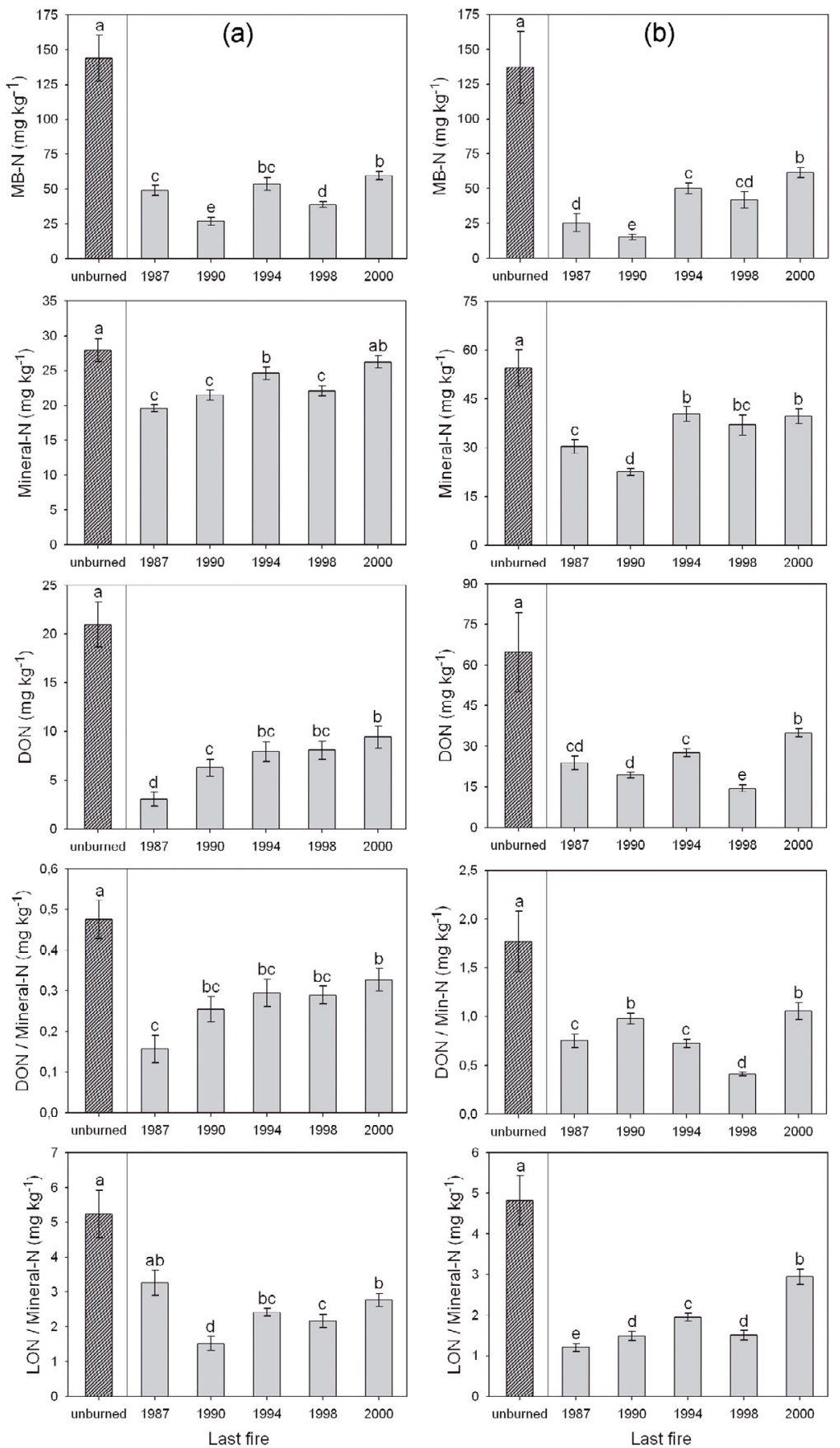

Figure 1. Microbial biomass N (MB-N), Mineral N, dissolved organic N (DON), DON-to-Mineral N ratio and LON-to-Mineral N ratio (LON = DON + MB-N) in burned and unburned plots. Results from the spring sampling (a) and the winter sampling (b) are shown. Different letters indicate significant differences (permutation test, $P<0.05$ ). 
Table III. Spearman correlation tests between variables in burned and unburned plots in spring and winter soil samples.

\begin{tabular}{lccccccccccccc}
\hline & \multicolumn{1}{c}{ Spring } & \multicolumn{1}{c}{ Winter } \\
\hline & \multicolumn{1}{c}{ MBN-MinN } & \multicolumn{2}{c}{ MBN-DON } & \multicolumn{2}{c}{ DON-MinN } & \multicolumn{2}{c}{ MBN-MinN } & \multicolumn{3}{c}{ MBN-DON } \\
\hline & $P$ & $R$ & $P$ & $R$ & $P$ & $R$ & $P$ & $R$ & $P$ & $R$ & $P$ \\
\hline Unburned & $<0.05 *$ & 0.364 & 0.38 & 0.146 & $<0.05 *$ & 0.708 & $<0.05 *$ & 0.413 & $<0.05 *$ & 0.532 & $<0.05 *$ & 0.672 \\
1987 & 0.38 & 0.166 & 0.39 & 0.393 & 0.49 & 0.321 & $<0.05 *$ & 0.620 & 0.28 & 0.267 & $<0.05 *$ & 0.493 \\
1990 & $<0.05 *$ & 0.357 & 0.11 & 0.328 & $<0.05 *$ & 0.635 & 0.29 & 0.163 & 0.67 & -0.069 & 0.09 & 0.224 \\
1994 & 0.95 & 0.008 & 0.10 & 0.305 & $<0.05 *$ & 0.388 & $<0.05 *$ & 0.409 & $<0.05 *$ & 0.360 & $<0.05 *$ & 0.572 \\
1998 & $<0.05 *$ & 0.213 & 0.75 & 0.042 & $<0.05 *$ & 0.502 & $<0.05 *$ & 0.713 & $<0.05 *$ & 0.628 & $<0.05 *$ & 0.767 \\
2000 & 0.06 & -0.248 & 0.19 & -0.203 & $<0.05 *$ & 0.639 & $<0.05 *$ & 0.429 & $<0.05 *$ & 0.554 & $<0.05 *$ & 0.404 \\
\hline
\end{tabular}

$n=60(1987, n=30) . \mathrm{MBN}=$ Microbial biomass N, MinN = mineral N, DON = Dissolved organic N, LON = Labile organic N $(\mathrm{MBN}+\mathrm{DON})$

control plots (unburned) than in the burned ones. DON values and the DON-to-Min-N ratio obtained in the spring sampling showed a significant linear decline $(\mathrm{d} f=3, F=19.46$, $P<0.05$ and $\mathrm{d} f=3, F=14.13, P<0.05$ respectively) as time elapsed after the fire (Fig. 1a). A similar trend, although not significant, was observed for mineral $\mathrm{N}$ in spring $(\mathrm{d} f=3$, $F=5.364, P=0.103)$ and for MB-N in winter $(\mathrm{d} f=3$, $F=6.873, P=0.078)$. No trend was observed for the remaining studied variables (Figs. 1a and 1b).

Significant differences in MB-N between spring and winter samplings were only detected in the plots that were burned in 1987 and 1990, with significantly higher values in the spring than in the winter sampling $(P<0.05)$. However, in all burned and unburned sampled plots, DON values were significantly lower in the spring than in the winter sampling. Similar differences between sampling dates were found for mineral $\mathrm{N}$ for all plots except for plots burned in 1990, where differences were not significant. A similar trend was observed for the DON-tomineral $\mathrm{N}$ ratio, but not for the LON-to-mineral $\mathrm{N}$ ratio, where spring values tended to be higher than winter values, although these differences were statistically significant only in the plots burned in 1987 and 1998.

There is a significant and positive correlation between MB$\mathrm{N}$ and Min-N, both in spring (Rho $=0.235, P<0.05)$ and in winter sampling (Rho $=0.551, P<0.05)$. Similar significant correlations were detected between MB-N and DON (spring: Rho $=0.178, P<0.05$; winter: Rho $=0.509, P<0.05)$ and between Mineral N and DON (spring: Rho $=0.667, P<0.05$; winter: Rho $=0.494, P<0.05)$. However, fire did not have any influence on these relationships, for either the winter or the spring sampling dates (Tab. III).

\section{DISCUSSION}

As predicted by our first hypothesis, fires decreased the $\mathrm{N}$ concentration in labile organic and inorganic forms. Thus, the amounts of MB-N, mineral $\mathrm{N}$, and DON experienced a significant decrease four years after the last fire (plots burned in 2000). Several studies have shown that soil microorganisms are affected by fire, both directly and indirectly, mainly through the effects of increased erosion, loss of fertility, or increase in toxic compounds (Certini, 2005; Dumonet et al., 1996). Thus, several authors have also found significant reductions on microbial biomass levels after a wildfire in different ecosystems (Hernández et al., 1997; Mabuhay et al., 2006), and as suggested above, the death of microorganisms due to soil warming and the declining quality and quantity of substrate after fire may explain this decrease (Sparling et al., 1994; Vance and Nadkarni, 1990). Furthermore, most authors have reported an increase in inorganic $\mathrm{N}$ pools just after fire (Kutiel and Naveh, 1987; Prieto-Fernández et al., 1993) due to ash deposition and increases in soil $\mathrm{pH}$ and temperature that improve mineralization rates after fire (Raison, 1979). However, the decrease of mineral $\mathrm{N}$ levels observed in our study several years after the wildfire has also been documented in other studies throughout the world (Chorover et al., 1994; Grogan et al., 2000). Increased plant uptake and the increase of erosion processes may determine the decrease in mineral $\mathrm{N}$ levels observed in our study (Carreira et al. 1994; Keeley and Zadler, 1978). Despite the great ecological significance of soil DON, and the increasing evidence of its uptake by plants, little is known about the factors that control its dynamics in the soil and even less is known about the effects of disturbances on these dynamics (Christou et al., 2006). We observed a clear reduction in soil DON amounts in burned plots compared to the control plots. After a wildfire, both a decrease in quality and amount of soil $\mathrm{C}$ are likely. Under these conditions, DON may represent a preferential labile $\mathrm{C}$ source for soil microbes, decreasing its soil concentration on a long-term basis (Jones and Kielland, 2002). On shorter time scales, losses by volatilization and pyrolysis or plant uptake, may explain a decline in soil DON (Raison, 1979; Smithwick, 2005).

Several years after fire, we expected to detect a slow recovery of organic and inorganic $\mathrm{N}$ concentrations approaching the levels of $\mathrm{N}$ in the unburned plots. Our expectations were based on both the activity of nitrogen fixers and the enhanced decomposition and mineralization rates expected under postfire soil conditions. However, none of the inorganic or organic $\mathrm{N}$ concentrations reached the $\mathrm{N}$ levels of the unburned plots, and no evidence of soil $\mathrm{N}$ recovery with time was observed. Indeed, some variables showed an inverse trend of decreasing $\mathrm{N}$ concentrations as time elapsed after fire. The lack of $\mathrm{N}$ recovery in burned soils observed in our study might be a consequence of the scale of our chronosequence $(20 \mathrm{y})$. Thus, forest fires may produce long-lasting deep transformations in soil quality, directly affecting different $\mathrm{N}$ pools through processes such as combustion, restructuring of organic molecules in complex recalcitrant forms and translocation of $\mathrm{N}$ between 
minerals and organic soil layers, and the increasing of soil erosion risks (Mabuhay et al., 2003; Smithwick, 2005). The combined effect of these mechanisms may be a long-term reduction of ecosystem productivity, preventing the ecosystem from recovery to unburned conditions (Wirth et al., 2002). Recovery after fire would depend on the ability of microbes and plants to immobilize the released nutrients, plant regeneration strategies, and the ability of resprouting vegetation for replenishing soil protection (Carreira et al., 1994; Keeley and Zadler, 1978). In the Pinus canariensis forest, a slow recovery of these protective elements is likely due to the low undergrowth plant cover, and the old pine population, which may restrict plant responses to new conditions, resulting in an erosion that continues operating for many years, and a lower recovery than would be expected (Carreira et al., 1994).

Microbial biomass $\mathrm{N}$ and DON decreased relatively more than mineral $\mathrm{N}$ in burned plots. This relative reduction in labile organic $\mathrm{N}$ fractions may be due to the poor quality of residual organic matter, which would limit microbial biomass and activity and its ability to produce DON (Hernández et al., 1997). Furthermore, combustion and erosion affect the organic superficial horizons more, with higher organic-to-inorganic $\mathrm{N}$ ratios (DeBano and Conrad, 1978). It is also possible that microorganisms of burned plots are using DON as a $\mathrm{C}$ and $\mathrm{N}$ source to a greater extent than in unburned plots, where a wider variety of $\mathrm{C}$ and $\mathrm{N}$ sources are present (Kranabetter et al., 2007).

We observed a decrease in soil MB-N in the winter samples compared to the spring samples. However, DON and mineral $\mathrm{N}$ increased in the winter samples. Mineral $\mathrm{N}$ accumulation observed in winter samples compared with spring samples suggested a decrease in plant uptake, due to pine inactivity induced by winter conditions. However, less $\mathrm{N}$ immobilization in microbial biomass may also be responsible as shown by the decrease of winter soil MB-N. Similarly, DON accumulation might also be explained by a winter decrease of DON uptake by plants. However, we have no evidence that plants growing in these pine forests are able to uptake DON, as has been found in other less productive ecosystems suffering from $\mathrm{N}$ limitation (Kranabetter et al., 2007).

Our results confirm the hypothesis that wildfires cause a long-term (17 y) decline in soil labile organic and inorganic $\mathrm{N}$ concentrations, including $\mathrm{N}$ immobilized by soil microbial biomass in the Pinus canariensis forests. Furthermore, almost two decades after wildfire, there is no sign of organic and inorganic $\mathrm{N}$ recovery to pre-fire levels. The magnitude of these observed changes suggests that pine forest wildfires may induce long-term changes in soil and plant primary production.

Acknowledgements: We thank the La Palma Government for enabling access and providing logistic support for the sampling expeditions, and Felix Medina, Rocío Paramá, Rosana Estévez, Javier Méndez, Gustavo Morales and Jesús Rodríguez for their valuable help with the field sampling and laboratory analysis. Special thanks are due to Jordi Cortina and Fernando Maestre for their assistance in the redaction of this manuscript, and Felisa Covelo for her continuous and unconditional help. This work was financed by the Ministerio de Ciencia y Tecnología of the Spanish Government (REN 2003-08620C0201; CGL 2006-13665-C02-01).

\section{REFERENCES}

Allen S.E., Grimshaw H.M., and Rowland A.P., 1986. Chemical analysis. In: Moore P.D. and Chapman S.B. (Eds.), Methods in Plant Ecology, Blackwell Scientific, Oxford, pp. 285-344.

Brookes P.C., Powlson D.S., and Jenkinson D.S., 1982. Measurement of microbial biomass phosphorus in soil. Soil Biol. Biochem. 14: 319329.

Cabrera M.L. and Beare M.H., 1993. Alkaline persulfate oxidation for determining total nitrogen in microbial biomass extracts. Soil Sci. Soc. Am. J. 57: 1007-1012.

Carreira J.A., Niell F.X., and Lajtha K., 1994. Soil nitrogen availability and nitrification in Mediterranean shrublands of varying fire history and successional stage. Biogeochemistry 26: 189-209.

Certini G., 2005. Effects of fire on properties of forest soils: a review. Oecologia. 143: 1-10.

Chorover J., Vitousek P.M., Everson D.A., Esperanza A.M., and Turner D., 1994. Solution chemistry profiles of mixed-conifer forests before and after fire. Biogeochemistry 26: 115-144.

Christou M., Avramides E.J., and Jones D.L., 2006. Dissolved organic nitrogen DeBano L.F. and Conrad C.E., 1978. The effect of fire on nutrients in a chaparral ecosystem. Ecology 59: 489-497.

D'Elia C.F., Steudler P.A., and Corwin N., 1977. Determination of total nitrogen in aqueous samples using persulfate digestion. Limnol. Oceanogr. 22: 760-764.

Dumontet S., Dinel H., Scopa A., Mazzatura A., and Saracino A., 1996. Post-fire soil microbial biomass and nutrient content of a pine forest soil from a dunal Mediterranean environment. Soil Biol. Biochem. 28: $1467-1475$.

Fernandes P.A.M., Loureiro C.A., and Botelho H.S., 2004. Fire behaviour and severity in a maritime pine stand under differing fuel conditions. Ann. For. Sci. 61: 537-544.

Galloway J.N., Townsend A.R., Erisman J.W., Bekunda M., Cai Z., Freney J.R., Martinelli L.A., Seitzinger S.P., and Sutton M.A., 2008. Transformation of the nitrogen cycle: recent trends, questions, and potential solutions. Science 320: 889-892.

González J.R., Palahí M., Trasobares A., and Pukkala T., 2006. A fire probability model for forest stands in Catalonia (north-east Spain). Ann. For. Sci. 63: 169-176.

Grogan P., Burns T.D., and Chapin III F.S., 2000. Fire effects on ecosystem nitrogen cycling in a Californian bishop pine forest. Oecologia 122: 537-544.

Hernández T., García C., and Reinhardt I., 1997. Short-term effect of wildfire on the chemical, biochemical and microbiological properties of Mediterranean pine forest soils. Biol. Fertil. Soils 25: 109-116.

Jones D.L. and Kielland K., 2002. Soil amino acid turnover dominates the nitrogen flux in permafrost-dominated taiga forest soils. Soil Biol. Biochem. 34: 209-219.

Keeley J.E. and Zedler P.J., 1978. Reproduction of chaparral shrubs after fire: a comparison of sprouting and seeding strategies. Am. Midl. Nat. 99: 142-161.

Kranabetter J.M., Dawson C.R., and Dunn D.E., 2007. Indices of dissolved organic nitrogen, ammonium and nitrate across productivity gradients of boreal forests. Soil Biol. Biochem. 39: 3147-3158.

Kutiel P. and Naveh Z., 1987. The effect of fire on nutrients in a pine forest soil. Plant Soil 104: 269-274.

Legout A., Walter C., and Nys C., 2008. Spatial variability of nutrient stocks in the humus and soils of a forest massif (Fougères, France). Ann. For. Sci. 65: 108.

Mabuhay J., Nakagoshi N., and Horikosh T., 2003. Microbial biomass and abundance after forest fire in pine forests in Japan. Ecol. Res. 18: 431-441.

Palese A.M., Giovannini G., Lucchesi S., and Perucci P., 2004. Effect of fire on soil C, $\mathrm{N}$ and microbial biomass. Agronomie 24: 47-53. 
Pappa A.A., Tzamtzis N.E., and Koufopoulou S.E., 2008. Nitrogen leaching from a forest soil exposed to fire retardant with and without fire: a laboratory study. Ann. For. Sci. 65: 210.

Prieto-Fernández A., Villar M.C., Carballas M., and Carballas T., 1993. Short-term effects of a wildfire on the nitrogen status and its mineralization kinetics in an atlantic forest soil. Soil Biol. Biochem. 25: $1657-1664$.

Raison R.J., 1979. Modification of the soil environment by vegetation fires, with particular reference to nitrogen transformations: a review. Plant Soil 51: 73-108.

Rambal S. and Hoff C., 1998. Mediterranean ecosystems and fire: the threats of global change. In: Moreno J.M. (Ed.), Large forest fires, Backhuys Publishers, Leiden, The Netherlands, pp. 187-213.

Rodríguez A., Durán J., Fernández-Palacios J.M., and Gallardo A., 2009. Wildfire changes the spatial pattern of soil nutrient availability in Pinus canariensis forests. Ann. For. Sci. 66: 210.

Sims G.K., Ellsworth T.R., and Mulvaney R.L., 1995. Microscale determination of inorganic nitrogen in water and soil extracts. Commun. Soil Sci. Plant. Anal. 26: 303-316.
Smithwick E.A.H., Turner M.G., Mack M.C., and Chapin III F.S.C., 2005. Postfire soil N cycling in Northern conifer forests affected by severe, stand-replacing wildfires. Ecosystems 8: 163-181.

Sparling G.P., Hart P.B.S., August J.A., and Leslie D.M., 1994. A comparison of soil and microbial carbon, nitrogen, and phosphorus contents, and macro-aggregate stability of a soil under native forest and after clearance for pastures and plantation forest. Biol. Fertil. Soils 17: $91-100$

Vance E.D. and Nadkarni N.M., 1990. Microbial biomass and activity in canopy organic matter and the forest floor of a tropical cloud forest. Soil Biol. Biochem. 22: 677-684.

Vitousek P.M., Gosz J.R., Grier C.C., Melillo J.M., Reiners W.A., and Todd R.L., 1979. Nitrate losses from disturbed ecosystems. Science 204: 469-474.

Wan S., Hui D., and Luo Y., 2001. Fire-Effects on nitrogen pools and dynamics in terrestrial ecosystems: a meta-analysis. Ecol. Appl. 11: 1349-1365.

Wirth C., Schulze E.-D., Lühker B., Grigoriev S., Siry M., Hordes G., Ziegler W., Backor M., Bauer G., and Vygodskaya N.N., 2002. Fire and site type effects on the long-term carbon and nitrogen balance in pristine Siberian Scots pine forests. Plant Soil 242: 41-63. 